\title{
The Evolution of Religion: How Cognitive By-Products, Adaptive Learning Heuristics, Ritual Displays, and Group Competition Generate Deep Commitments to Prosocial Religions
}

\author{
Scott Atran \\ CNRS \\ Institut Jean Nicod \\ Paris, France \\ \& \\ John Jay College of Criminal Justice \\ New York, NY, USA \\ \& \\ ISR and Ford School of Public Policy \\ University of Michigan \\ Ann Arbor, MI, USA \\ satran@umich.edu \\ Joseph Henrich \\ Department of Economics and Department of Psychology \\ University of British Columbia \\ Vancouver, BC, Canada \\ joseph.henrich@gmail.com
}

\begin{abstract}
Understanding religion requires explaining why supernatural beliefs, devotions, and rituals are both universal and variable across cultures, and why religion is so often associated with both large-scale cooperation and enduring group conflict. Emerging lines of research suggest that these oppositions result from the convergence of three processes. First, the interaction of certain reliably developing cognitive processes, such as our ability to infer the presence of intentional agents, favors-as an evolutionary by-product - the spread of certain kinds of counterintuitive concepts. Second, participation in rituals and devotions involving costly displays exploits various aspects of our evolved psychology to deepen people's commitment to both supernatural agents and religious communities. Third, competition among societies and organizations with different faith-based beliefs and practices has increasingly connected religion with both within-group prosociality and between-group enmity. This connection has strengthened dramatically in recent millennia, as part of the evolution of complex societies, and is important to understanding cooperation and conflict in today's world.
\end{abstract}

\section{Keywords}

by-product hypothesis, credibility enhancing displays, cultural transmission, cooperation, group competition, high gods, minimally counterintuitive, morality, religion, rise of civilization 
[An] advancement in the standard of morality and an increase in the number of well-endowed men ... who, from possessing in a high degree the spirit of patriotism, fidelity, obedience, courage, and sympathy, were always ready to give aid to each other and to sacrifice themselves for the common good, would be victorious over other tribes.

\section{— Charles Darwin, The Descent of Man}

This synthesis integrates insights from studies of the cognitive foundations of religion with evolutionary approaches to human cooperation to derive a deeper understanding of the origin and development of prosocial religions. We argue that the cultural evolution of prosocial religions and the historical rise of large-scale civilizations involve the dynamic interaction of the by-products of adaptive cognitive mechanisms (e.g., minimally counterintuitive beliefs and overextended agent concepts), adaptive learning heuristics (e.g., emulation of successful and prestigious individuals), credibility-enhancing ritual displays (e.g., self-sacrifice and costly commitments to seemingly preposterous beliefs), and cultural group selection for those packages of rituals, devotions, and beliefs that best sustain in-group prosocial norms (e.g., monumental undertakings, sacred values).

Many religions pose an evolutionary enigma because they require costly commitments to beliefs that violate both core aspects of logical consistency and our intuitive expectations about how the world works, both of which are otherwise crucial for successfully navigating the world (Atran and Norenzayan 2004). Religious practices are often costly in terms of material sacrifice (ranging from human sacrifice to prayer time), emotional expenditure (inciting fears and hopes), and cognitive effort (maintaining conflicting models about the nature of the world). One anthropological review of religious offerings concludes: "Sacrifice is giving something up at a cost... 'Afford it or not,' the attitude seems to be" (Firth 1963).

At the same time, the origin of large-scale cooperative human societies is also an evolutionary puzzle because people frequently cooperate and trade with non-relatives in ephemeral interactions (Fehr and Fischbacher 2003). Thus, while the evolutionary mechanisms associated with kinship, reciprocity, and reputation clearly influence cooperation in important ways, they do not capture the fullest extent of human prosociality. Kinship cannot explain cooperation among non-relatives (Henrich and Henrich 2007), though "fictive kinship"- a cultural manipulation of kin psychology - may contribute to mobilizing larger groups (Johnson 1987; Atran 2003). Reciprocity does not suffice to explain cooperation beyond dense social networks, small villages, or tightly knit neighborhoods (Hruschka and Henrich 2006; Allen-Arave et al. 2008; Atran 2010). Neither direct nor indirect reciprocity can explain cooperation in transient interactions in large populations, because reputational information rapidly degrades as a function of population size, or in large-group interactions such as those associated with many kinds of public goods or common dilemmas (Boyd and Richerson 1988; Panchanathan and Boyd 2003; Nowak and Sigmund 2005; Mathew and Boyd 2009). Even more telling is that none of these mechanisms explains the variation in cooperation among human societies, or the massive expansion of cooperation in some societies over the last ten millennia (Henrich et al. 2005; Atran 2010).

Converging lines of field and experimental evidence suggest that cultural evolution, building on certain innate cognitive foundations, has favored the emergence of beliefs in powerful moralizing deities concerned with the prosocial behavior of individuals beyond kin- and reciprocity-based networks (Norenzayan and Shariff 2008). Cross-cultural analysis of 186 societies has found that larger and more complex societies were much more likely to subscribe to potent deities directly concerned with morality and willing to punish norm violators (Roes and Raymond 2003; Johnson 2005). Studies conducted across a diverse range of societies including foragers, farmers, and herders, show that professing a world religion predicts greater fairness toward ephemeral interactants (Henrich et al. 2010). Experiments with North Americans show that unconsciously activating religious concepts lead to reduced cheating and greater generosity toward strangers (Bargh and Chartrand 1999; Mazar and Ariely 2006; Shariff and Norenzayan 2007), except among ardent atheists. Together, these cross-cultural, historical, and experimental findings suggest that (1) religion - as a phenomenon with potentially deep roots (Klein 1989) - has not always been about high moralizing gods and (2) modern world religions may have evolved to create a potent linkage between the supernatural and the prosocial. Thus, we hypothesize that cultural evolutionary processes, driven by competition among groups, have exploited aspects of our evolved psychology, including certain cognitive by-products, to gradually assemble packages of supernatural beliefs, devotions, and rituals that were increasingly effective at instilling deep commitment, galvanizing internal solidarity, and sustaining larger-scale cooperation.

\section{Ordinary Cognition Produces Extraordinary Agents}

Humans are purpose-seeking, cause-inferring, story-telling animals (Gazzaniga et al. 2009). As Hume noted in The Natural History of Religion, the greater the impact of events on our lives, the greater is our drive to impose purpose and coherence on those events. This view is backed by a recent experiment in which people were asked what patterns they could see in arrangements of dots or stock market figures (Whitson and Galinsky 2008). Before asking, the experimenters made half the participants feel a lack of control. Those who experienced a lack of control were more likely to see patterns and processes underlying the randomness, suggesting that under uncertainty 
we are more likely to find preternatural explanations for the randomness. Both cross-cultural experiments and surveys indicate that people more readily ascribe to the veracity of narratives containing counterintuitive elements (e.g., miracles) when primed with death (Norenzayan and Hansen 2006), or when facing danger or insecurity, as with pleas of hope for God's intervention during wartime (Argyle and Beit-Hallahmi 2000). Such findings help explain both cross-national analyses showing that a country's religiosity (devotion to a world religion) is positively related to its degree of existential insecurity (Norris and Inglehart 2004), and why certain kinds of religions enjoy revivals in challenging times. The issue then becomes: how and why does purpose-seeking and cause-inferring so often deliver supernatural agents?

Religious traditions center on supernatural agents, such as gods, angels, or ancestor spirits. This includes religions such as Buddhism and Taoism, which doctrinally eschew personifying the supernatural, but whose adherents routinely worship an array of deities that behave in ways that violate our intuitive expectations about how the world works (Pyysiäinen 2003). Mundane agent concepts are central players in what psychologists refer to as folkpsychology, associated with a Theory of Mind module(s) (ToM), which is a cognitive system devoted to making inferences about the beliefs, desires, and intentions of other minds (Baron-Cohen 1995). Recent functional magnetic resonance imaging (fMRI) studies confirm that people's statements about God's involvement in social events, as well as the deity's purported emotional states, reliably engage ToMrelated regions of the brain (Kapogiannis et al. 2009).

Agent concepts may be hair-trigger in our cognitive processing, allowing us to readily respond under uncertainty to potential threats by intelligent predators (Guthrie 1993). From this evolutionary vantage, agent's proper evolutionary domain encompasses animate species, but its actual domain inadvertently extends to moving dots on computer screens, voices in the wind, faces in clouds, complicated contrivances like eyes, and virtually any complex design or uncertain circumstance of unknown origin (Sperber 1996). Children and adults spontaneously interpret the contingent movements of dots and geometrical forms on a screen as interacting agents with distinct goals and internal goal-directed motivations (Heider and Simmel 1944; Bloom and Veres 1999; Csibra et al. 1999). Young children spontaneously overattribute agency to all sorts of entities (clouds, computers), and may thus be predisposed to construct agent-based representations of many phenomena (Keleman 2004). Such reliably developing programs provide efficient reactions to a wide-but not unlimited - range of stimuli that would have been statistically associated with the presence of dangerous agents in ancestral environments. Mistakes, or "false positives," would usually carry little cost, whereas a true response could provide the margin of survival. This reactive bias was likely adaptive, at least until supernatural agents were harnessed by cultural evolution to begin demanding costly actions and cooperation, under threat of divine punishment or offers of sublime rewards.

How do our minds make agent concepts into gods? Cognitive approaches propose that supernatural concepts exploit ordinary mental processes to construct counterintuitive concepts (Boyer 2001; Atran 2002; Barrett 2004). Religious beliefs are counterintuitive because they violate universal expectations about the world's mundane structure. This includes the basic categories of our "intuitive ontology" (i.e., the ontology of our semantic system), such as person, animal, plant, and substance (Whythe 1993; Sperber et al. 1995). Experimental studies reveal that children across cultures do not violate such categorical constraints in learning word meaning; for example, people cannot literally melt, and neither can animals joke, trees walk, nor rocks tire (Keil 1979). Experiments with Americans and Indians illustrate a gap between religious utterances and the mental processing of religious concepts (Barrett and Keil 1996; Barrett 1998). When asked to describe their deities, subjects produced abstract theological descriptions of gods that are able to (1) do anything, including anticipating and reacting to everything all at once, (2) know the right thing to do, and (3) dispense entirely with perceptual information and calculation. However, when asked to respond to narratives about these same gods, people interpreted their deities as being in only one place at a time, puzzling over alternative actions, and looking for evidence to make a decision. In short, people mentally represent gods using our intuitive ontology, so abstract theological propositions give little insight into how people actually think about supernatural agents (Malley 2004). Much recent work suggests this intuitive ontology results from, or interacts with, certain universal modes of causal construal, including folkmechanics (object cohesion, contact, and continuity in movement), folkbiology (teleological development of species-like essences and relations), and folkpsychology (intentional, goal-directed, interactive agents).

Most religious beliefs minimally violate the expectations created by our intuitive ontology and these modes of construal, thus creating cognitively manageable and memorable supernatural worlds. For example, agents that resemble us emotionally, intellectually, and physically except that they can move through solid objects and live forever (angels, ghosts, and spirits) fit the bill. Table 1 provides examples of minimal violations.

Cognitive approaches hypothesize that although intuitive concepts transmit well, concepts that minimally deviate from intuition transmit better, while those that deviate greatly cannot transmit successfully because they overload cognitive processes that drive inferential reasoning and relevance (Atran and Sperber 1991). Invisible statues that cry, exist in two places at once, and get hungry only on leap years are not easy to entertain. Minimally counterintuitive concepts are remembered and 
Table 1. Mundane relations between universal categories and modes of reasoning. Changing any one cell $(+$ to - or - to +$)$ yields a minimal counterintuition. Thus, switching the cell ( - folkpsychology, substance) to (+ folkpsychology, substance) yields a thinking talisman; switching ( + folkpsychology, person) to (- folkpsychology, person) yields a zombie (Barrett 2000; Atran and Norenzayan 2004).

\begin{tabular}{|c|c|c|c|c|c|}
\hline \multirow[b]{3}{*}{$\begin{array}{l}\text { Semantic } \\
\text { Categories }\end{array}$} & \multicolumn{5}{|c|}{ Belief Domains (and Associated Properties) } \\
\hline & \multirow{2}{*}{$\begin{array}{l}\text { Folkmechanics } \\
\text { Inert }\end{array}$} & \multicolumn{2}{|c|}{ Folkbiology } & \multicolumn{2}{|c|}{ Folkpsychology } \\
\hline & & Vegetative & Animate & $\begin{array}{l}\text { Psycho-Physical, e.g., } \\
\text { Hunger, Fatigue, etc. }\end{array}$ & $\begin{array}{l}\text { Epistemic, e.g., } \\
\text { Belief, Desire, etc. }\end{array}$ \\
\hline Person & + & + & + & + & + \\
\hline Animal & + & + & + & + & - \\
\hline Plant & + & + & - & - & - \\
\hline Substance & + & - & - & - & - \\
\hline
\end{tabular}

retransmitted more readily than either intuitive or highly counterintuitive concepts. Recall experiments indicate that minimally counterintuitive concepts and beliefs enjoy a cognitive advantage in memory and transmission over intuitive concepts and mundane beliefs (Barrett and Nyhof 2001). Results have been observed immediately, as well as after a three-month delay, in samples from the United States, France, Gabon, Nepal (Boyer and Ramble 2001), as well as from Maya (Atran and Norenzayan 2004). Whether counterintuitive concepts are believed in, or committed to, more is another matter (think Jesus vs. Zeus), which is addressed below (also see Gervais and Henrich forthcoming).

The advantages in mnemonic and transmittability for minimally counterintuitive representations beg the question of why such representations don't occupy most of scriptures, folktales, and myths. The Bible or the Koran, for example, involve successions of mundane events-walking, eating, sleeping, marrying, fighting, and suffering-interspersed with a few counterintuitive occurrences, often involving miracles or the appearance of supernatural agents. One explanation is that counterintuitive ideas are transmitted as elements in narrative structures. Studies have explored this by examining (1) the cognitive structure of folktales, and (2) the relative cultural success of each tale (Norenzayan et al. 2006). Minimally counterintuitive folktales (containing two to three supernatural events or objects) were substantially more widespread than folktales containing fewer counterintuitive elements (less than two) or those with too many counterintuitive elements (more than three).

In brief, counterintuitive concepts and beliefs, as long as they come in small doses, help people remember and presumably retransmit the intuitive statements, as well as the underlying knowledge that can be inferred from them. A small proportion of minimally counterintuitive elements give a story a mnemonic advantage over stories with no or too many counterintuitive elements. This dual aspect of supernatural belief sets-commonsensical and counterintuitive- renders them intuitively compelling yet fantastic, eminently recognizable but surprising. Cross-cultural experiments indicate that such beliefs grab attention, activate intuition, mobilize inference, and can accommodate seemingly contrary events and interpretations, in ways that facilitate their mnemonic retention, cultural transmission, and historical survival.

\section{Natural Origins of Faith}

The above helps explain the success of, for example, folktales and scriptures. However, this approach misses the difference between Moses' miracles and Mickey Mouse's antics (Atran 1998). Or, why the faithful of one religion do not adopt beliefs in the gods of other religions once they learn about them (Gervais and Henrich forthcoming). So, the question is why do people become deeply committed to particular counterintuitive agents or stories-so committed that they would die for their beliefs?

We are a cultural species. Unlike other animals, humans have evolved to rely heavily on acquiring behavior, beliefs, motivations, and strategies from others in their group. These psychological processes, shaped by natural selection, focus our attention on both those domains and individuals likely to possess fitness-enhancing information (Henrich and Gil-White 2001; Richerson and Boyd 2005). Human social learning generates vast bodies of know-how and complex practices that accumulate and improve over generations. Studies of small-scale societies show that survival and reproduction are dependent on cumulative bodies of information related to hunting (animal behavior), edible plants (seasonality, toxicity, etc.), medical knowledge, technical manufacture, and so on (Liebenberg 1990; Henrich and McElreath 2003; Henrich 2008).

Because of the dependence that human ancestors increasingly had to place on such complex, often nonintuitive, products of cumulative cultural evolution, natural selection may have favored a willingness to rely on culturally acquired 
information-filtered through our adaptive biases - over our direct experience or basic intuitions. To see this, consider that many foragers process plant foods to remove toxins without conscious knowledge of what happens without processing (Beck 1992). Such foods often contain low dosages of toxins that cause little harm for months or even years, and don't badly damage the food's flavor. However, such toxins will accumulate and eventually cause severe health problems and death. A naïve learner who favors his own experience of eating the foods without the arduous processing will do less work in the short run, but possibly die in the long run. Place faith in traditional practices, without understanding why, can be adaptive. Similarly, manufacturing complex technologies or medicines often involves a sequence of important steps, most of which cannot be skipped without producing an inferior outcome. Experimentation is of limited use in rearranging or dropping steps because even a relatively small number of steps yields a combinatorial explosion of possible alternative procedures. Learners must have faith, and copy all steps. This suggests that a willingness to sometimes rely on faith-to believe in cultural traditions over experience or intuitions - is likely a product of evolving in a world with complex cultural adaptations.

Supporting evidence comes from developmental psychology, which documents a potent tendency for "over-imitation" in children, and recently demonstrated how deeply overimitation influences our acquisition and encoding of concepts (Lyons et al. 2007). This comes across most starkly in studies comparing children and chimpanzees. When both species observe demonstrations of a task involving multiple steps, children accurately copy all steps, including steps that direct visual inspection would suggest are unnecessary. Chimpanzees do some copying but skip unnecessary steps, leading them to more efficient repertoires than children (Horner and Whiten 2005). Children implicitly assume that if the model performed a seemingly unnecessary action, it was probably important, even if they cannot understand precisely why.

With the evolution of language, this faith in culturally transmitted information became vulnerable to exploitation by individuals-particularly successful and prestigious individuals - able to transmit practices or beliefs they themselves might not hold. Language makes exaggeration, distortion, manipulation, and deception easy and cheap. Before language, learners observed and inferred people's underlying beliefs or desires by their behavior. Those wishing to deceive would have to actually perform an action to transmit it. To avoid being manipulated by models proficient at altering or exaggerating commitments to certain beliefs, evolutionary approaches suggest that humans may have evolved cognitive abilities that examine the fit between a model's words (expressed beliefs) and actions. In figuring out who to learn from, learners consider both a model's cues of success, skill, and prestige (among other cues) and whether a models' expressed beliefs are supported by diagnostic actions that permit an assessment of the model's underlying degree of commitment to their expressed beliefs. For example, if a potential model rails against prostitution, but then uses prostitutes for his own clandestine recreation, a learner should de-weight this model's influence in cultural transmission with regard to prosecuting prostitution. This means that if a model's belief causes him to perform "costly displays"- that is, actions that would be too costly for someone with different beliefs to perform-learners should be more willing to learn from this model. If a model is successful or prestigious in the eyes of learners, and performs costly displays cueing deep commitment to his expressed beliefs, then learners should more readily adopt and believe in (be committed to) the models' expressed beliefs (Henrich 2009).

Experimental findings support this. Thus, young children are generally unwilling to sample a novel food offered by a stranger as "something to eat" without first seeing the stranger eat it (Harper and Sanders 1975). Developmental studies of the transmission of altruistic giving show that neither preaching nor exhortation to charity is effective without opportunities to observe costly giving by models (Henrich and Henrich 2007). Studies of children's beliefs about the existence of entities like intangible germs, angels, and mermaids show that children only subscribe to those agents whom adults seem to endorse through their daily actions, and remain skeptical of unendorsed supernatural agents (Harris et al. 2006). Similarly, interviews with a diverse sample of parents from highly religious Christian, Jewish, Mormon, and Muslim families reveal that parents see religion holding their children on a virtuous life course primarily because of their costly investments in "practicing (and parenting) what you preach" (Marks 2004).

This suggests an approach to devotions (fasting, celibacy, etc.) and rituals as having evolved culturally (at least in part) to deepen people's commitments to counterintuitive beliefs. Counterintuitive beliefs have a mnemonic advantage, but not a belief advantage. Both direct experience and our own intuitions often contradict counterintuitive beliefs, and reality does not readily provide decisive evidence in their favor. (There are many potentially counterintuitive beliefs that can be empirically grounded through arduous scientific effort-think quantum teleportation, evolution, etc.- - but common sense and experience don't favor even these beliefs.) This puts counterintuitives at a disadvantage relative to mundane or intuitive beliefs. Rituals and devotions can help overcome this disadvantage through acts of costly commitment.

In this view, costly ritual or devotional acts may have evolved as a means to convince learners of the personal commitment of either the rest of the congregation (exploiting conformist biases in our learning) or of locally prestigious models (Henrich 2009). Rituals and devotions exploit our reliance on diagnostic actions to deepen commitment to counterintuitive beliefs. They also link performance of costly acts to 
social success, thereby perpetuating the transmission of beliefcommitment across generations. Formal cultural evolutionary models show that costly displays (e.g., ritual sacrifice) can interlock with and sustain counterintuitive beliefs, which would not be otherwise sustained by cultural evolution. By contrast, fairy tales are counterintuitive, easily remembered, and may help to transmit moral messages by grabbing attention with themes having emotional impact; but nothing is socially imperative or sacred about them or their message. No one in the learner's community demonstrates via costly acts their deep commitment to the truth of such stories, actors, or ideas.

Because of our adaptive need, at times, to rely wholly on cultural information in the face of inconsistent experience or contradictory implications, natural selection likely favored something of a psychological immune system that cements adherence to adopted beliefs. Experiments suggest that once people sincerely commit to religious beliefs, attempts to undermine them through reason and evidence can stimulate the strengthening of personal commitments (Festinger et al. 1956). Since many religious beliefs are logically inscrutable and immune to empirical falsification, a failed prophecy (direct evidence) may mean that more introspection and commitment is needed.

These lines of reasoning and evidence suggest that commitment to supernatural agents tends to spread in a population to the extent it elicits costly displays, usually in the form of ritual ceremonies, offerings, devotions, and sacrifices. When community leaders and congregations demonstrate commitment to supernatural beliefs in costly rites, observers who witness these commitments are more inclined to trust and follow participants. Such trust and following often extend to wider sets of mundane beliefs and associated actions because (1) people tend to follow, and give the benefit of doubt to, models with proven success and commitment in one valued domain as they move into other domains (hence, advertisers get famous people to sell their wares) (Henrich and Gil-White 2001); and (2) many counterintuitive beliefs violate our intuitive ontology, and are thus literally preposterous (like many poetic tropes); they can only be meaningfully interpreted in terms exogenous to the beliefs themselves. Consequently, religious trust and following carry over to other beliefs and actions associated with ritualized actions, including cooperative works, charity, commerce, moral norms, and warfare.

Supernatural agents that incentivize costly sacrifices will tend to spread, creating an emerging linkage between degree of commitment to belief and costly displays. For example, alongside prohibitions against various social ills (e.g., murder, adultery, and theft), God commanded the Israelites to keep holy the Sabbath or suffer death. Demands for rituals, devotions, and sacrifices guarantee intergenerational transmission of deep commitments (Alcorta and Sosis 2005), as children infer deep commitment from costly actions of adults (Henrich 2009).
Because the deeply committed actually believe in the agent's incentives, sacrifices and rituals needn't seem (subjectively) costly.

Religions have culturally evolved to deploy a variety of other means to ratchet up faith and commitment. Faith in otherwise inscrutable content is deepened and validated by communion: collectively engaging emotions and motivations using music, rhythm, and synchrony. Of people reporting a religious experience, music is the single most important elicitor of the experience, followed by prayer and group services (Greeley 1975). Listeners as young as three years old reliably associate basic emotions — anger, sadness, fear, joy—with musical structures (Trainor and Trehub 1992). Recent study finds that strangers acting in synchrony-marching, singing, and dancing - cooperate more in subsequent group exercises, even in situations requiring personal sacrifice. Synchronous action (rhythmically moving together) increases cooperation by strengthening social bonds among group members, even when no positive emotion is attached to the movement (Wiltermuth and Heath 2009). The ability of music, rhythm, and synchrony to instill commitment and trust is also apparently why military drills and routines have been developed over the centuries to train soldiers and build armies (McNeil 1982).

This indicates that groups and institutions that survive and spread will possess both costly displays (devotions and rituals) of commitment and values that glorify such sacrifices for group beliefs. The Navajo, for example, are among the most successful cooperators and survivors of Native American groups, with men spending upwards of one-third, and women one-fifth, of their productive time on "priestly rites" (Kluckholn and Leighton 1946). Historical studies suggest that early Christianity spread to become the majority religion in the Roman Empire through costly displays such as martyrdom and charity (e.g., risking death by caring for sick non-Christians during epidemics; Stark 1997). Strengthening the group through ritual participation and costly displays also applies to a variety of modern movements for civil and human rights that grow by "waging peace" in the battle for public opinion, including those modeled on the nonviolent doctrines and costly commitments (imprisonment, harassment, etc.) of Gandhi and M. L. King (Smith 1996). Martyring spiritual leaders often stimulates the spread of their ideas by providing persuasive displays of the leader's deep commitment (Atran 2010).

Below, we sketch a cultural evolutionary process that assembles these otherwise disparate elements into a general account of the evolution of religions.

\section{Coevolution of Counterintuitive Beliefs and Norms for Complex Societies}

Counterintuitive beliefs are readily recalled and retransmitted. Rituals and devotions involving costly displays, music, 
rhythm, and synchrony can ratchet up the belief in, and commitment to, these counterintuitive beliefs. Now, the questions are (1) how do these elements of effective rituals and devotions get assembled and linked with particular supernatural agents?; (2) why do these supernatural agents so favor prosocial behavior, by forbidding stealing, lying, murdering, adultery, and so forth?; and (3) why does this seem more prevalent in recent and increasingly large and complex societies? A rising tide of evidence suggests that religious beliefs, rituals, devotions, and social norms have coevolved in interlocking cultural complexes in a process driven by competition among alternative complexes.

As a species we rely heavily on acquiring key aspects of our behavior by observing others. Humans readily acquire social strategies, practices, beliefs, and preferences via cultural learning in ways consistent with evolutionary predictions (Henrich and McElreath 2003). Children acquire altruistic behaviors or other costly norms via observation and inference, and will spontaneously apply imitated standards to others, sanctioning them if necessary (Henrich and Henrich 2007; Rakoczy et al. 2008). Game theoretic analyses show that when cultural learning is combined with social interaction, a variety of different stable states (i.e., social norms or institutions) emerge. Unlike genetic transmission, this is even true in larger scale cooperative endeavors (Henrich and Boyd 2001; Panchanathan and Boyd 2004), in which both cooperative and defecting states can remain stable. When the aforementioned cognitive mechanisms for weighting costly displays are included as part of cultural learning, belief-action combinations yield many different stable states, including those in which the actions are individually costly, and potentially cooperative (Henrich 2009).

Existence of alternative stable sets of norms across human societies creates conditions in which competition among groups will favor the emergence of prosocial norms - that is, norms that lead to success in competition with other groups. The most important norms are likely to be those that increase cooperation (e.g., in warfare and economic production) or reduce within-group conflict, by regulating sexual relationships or managing disputes. Because this process involves competition among stable states, modeling shows that it does not suffer the challenges typically associated with the genetic group selection of altruism (Boyd and Richerson 2002).

This process is capable of assembling those combinations of supernatural beliefs, rituals, and devotions that most reinforce cooperative or other prosocial norms. Religious elements can operate in at least four interrelated ways. First, observation and participation in costly rituals are likely to induce deep commitment to associated norms, leading to greater intrinsic motivation to comply (Henrich 2009). Second, supernatural policing and incentives (heaven vs. hell) can buttress more worldly norm-sustaining mechanisms, such as punishment, signaling, and reputation (Gintis et al. 2001; Henrich and Boyd 2001; Panchanathan and Boyd 2004). By augmenting these mechanisms, supernatural beliefs have culturally selective advantages over purely secular mechanisms (Johnson 2005). At the margins, the additional psychological threat of supernatural incentives reduces the costs of punishing violators, provides a threat when no human eyes are watching, and may tilt the balance in situations when the benefits of defecting (charging a vast enemy) exceed the potential worldly costs. If a transgressor has faith in divine awareness and retribution, then external policing, capture, and punishment "automatically" come from within. By reenforcing worldly mechanisms where they are weak (e.g., monitoring large populations), supernatural beliefs can help extend the scale and intensity of cooperation. Third, when supernatural punishment is either indiscriminate or collective, third parties have a direct incentive to keep norm violators in line. If people believe that their god will punish everyone (say, by a drought) for the misdeeds of a few (e.g., adultery), then everyone has an incentive to keep everyone else in line.

The fourth way religion can galvanize prosocial norms is by making gods the authors of sacred canons or values that authenticate society - in the minds of believers - as having an existence above a mere aggregation of its individuals and institutions (Durkheim 1995; Wilson 2002). Beyond simply the authority of authorship, the ineffability of sacred "propositions" (e.g., "God is merciful to believers," or "this land is holy") effectively places them beyond logical or empirical scrutiny (Rappaport 1999). Recent work reveals that children's beliefs in God as the creator of everything favors essentializing of social categories, meaning that religious beliefs about divine creators predict the inferring that ethnic/religious category membership is stable (immutable: these effects seem limited to human categories, and do not influence judgments about artifacts or animals). This suggests that competition among socioreligious groups will favor beliefs that galvanize and reify group membership by extending our intuitive system for essence-based inferences (used for thinking about biological kinds; Atran 1998) to the relevant human social categories (Diesendruck and Haber 2009). By sparking our tendency to essentialize some categories (e.g., biological species), beliefs in supernatural creators may facilitate (psychologically) the unification of diverse tribes into a single, stable, immutable people_-God's people.

The same evolutionary process will favor distinct markers of group members, often in the form of taboos. These emerge as nonnegotiable prohibitions about beliefs and behaviors that systematically covary with sacred (less observable) beliefs and values (Durkheim 1995; Wilson 2002). Punishment for transgression of taboos provides concrete markers and proof of the meaning and importance of what is sacred for a society. Together, sacred values and taboos bound moral behavior at 
the most basic level of conduct in society (sex, diet, dress, and greetings) and at the most general level (warfare, rule, work, and trade). Together with religious rituals, devotions, and insignia, such practices can foster a cohesive group identity and increase solidarity vis-à-vis other groups. Here religion exploits and extends our "tribal psychology" that has long marked group boundaries through language, dialect, and dress (McElreath et al. 2003).

For example, the Hebrew Kingdom of Judah used circumcision, dietary laws, and a prohibition against work on the Sabbath (etc.) as displays of commitment to their God. This enabled the alliance of Hebrew tribes to set themselves apart from coastal peoples (e.g., Philistines, Canaanites) and forged a unification that withstood stronger invaders (e.g., Egyptians, Babylonians) (Sweeney 2001). Violating the Sabbath, along with idolatry, were considered the gravest violations and punishable by death (Phillips 1970). These were both costly and arbitrary markers of corporate identity relative to the concrete needs of social life shared with other groups (in contrast to prohibitions on stealing, adultery, murder, etc.). Disregard of these was considered a reliable signal of sin and failure of commitment. From this perspective, groups using such costly markers succeed because they (1) transmit commitment in the next generation, (2) eliminate, or identify, those lacking sufficient commitment to the group and its $\operatorname{god}(\mathrm{s})$ (Irons 1996; Sosis and Alcorta 2003), and (3) psychologically demarcate the group in ways that engage our tendency to essentialize and reify group boundaries.

Norms are often attached to powerful emotions (anger, guilt, shame) that can be amplified by certain religious beliefs into dread, awe, or anxiety. This leads to strong reactions against norm violators that range from bad-mouthing to banishment, and from manhandling to murder. Experiments show that when norms are associated with the sacred, they become emotionally charged and less influenced by material calculations and tradeoffs (Tetlock 2003). In conflict situations, as in the Middle East, recent research reveals that material offers from one group to another proposing that norms associated with sacred values be relaxed or abandoned generate moral outrage, and increase people's readiness to support lethal violence. Such sacred values appear to be somewhat immune to the rationality of realpolitik or the marketplace, implying that a "business-like" approach to negotiations in conflicts involving sacred values may backfire (Atran et al. 2007; Ginges et al. 2007; Dehghani et al. 2009). From our perspective, increasing the material incentives to a believer in exchange for violating sacred values might result in substantial increasing of the signaling value obtained from rejecting the material payoffs. The target of the signal might be God, one's fellows, or one's self.

The line sketched here allows some predictions about the historical emergence of supernatural agents. Gods of increasingly complex societies should evolve to be more concerned with (1) in-group cooperation (help your co-religionists), harmony (no stealing, lying, or adultery), and fair exchange, (2) sexual and family relations (increasing reproduction of new adherents), and (3) the performance of commitment-inducing rituals (Roes 1995; Roes and Raymond 2003; Johnson 2005). To better police and reward adherents, the gods of emerging complex societies need more knowledge of mortal behavior (evolution of omniscience) and more power to reward and punish (thus, an afterlife in heaven or hell). This allows gods to monitor people in ephemeral or anonymous situations, and to provide potent incentives, if they can instill deep commitment. Along these lines, beliefs in an eternal, blissful afterlife for the faithful likely emerged only during and after the first millennium B.C. in Eurasia, with the rise of cosmopolitan religions such as Hinduism, Mahayana Buddhism, and Christianity (McNeil 1991).

\section{The Religious Rise of Civilizations}

Scholars have long suspected a link between certain religious forms and the emergence of complex societies. In the 14th century, historian Ibn Khaldûn examined different waves of invasion in the Maghreb and argued that enduring dynastic power stems from religious "group feeling," with its ability to unite desires, inspire hearts, and support mutual cooperation (Khaldûn 2005). Historical work suggests that the beliefs, rituals, and norms (e.g., inheritance rules, ethnic equality, judicial procedures) of Islam spread initially by providing a means of unifying the warring Arabic tribes, giving them the ability to cooperate, conquer, and gradually assimilate surrounding peoples (Levy 1957). Contemporary studies indicate that Islam spread into Sub-Saharan Africa by drawing people into tighter religiously-based networks of trust that facilitate trade and economic success (Ensminger 1997). As expected, this process is galvanized by costly devotions and rituals (fasting, frequent prayer, taboos on pork and alcohol) that demarcate believers from everyone else. Similar considerations apply to the ongoing spread of evangelical Protestantism in Asia, Africa, and Latin America (Freston 2001).

The archaeological record reveals a clear, coevolutionary connection between religion, ritual, and complex societies. Recent finds indicate that rituals became much more formal, elaborate, and costly as societies developed from foraging bands into chiefdoms and states (Marcus and Flannery 2004; cf. Whitehouse 2004). In Mexico before 4000 B.P., for example, nomadic bands relied on informal, unscheduled, and inclusive rituals. The same goes for contemporary foragers, such as the San of Africa's Kalahari desert, whose ad-hoc rituals (e.g., trance dancing) include all community members, and are organized according to the contingencies of rainfall, hunting, and illnesses (Lee 1979).

Then, with the establishment of permanent villages and multi-village chiefdoms (4000-3000 B.P.), rituals are managed 
by social achievers (prestigious "Big Men" and chiefs) and scheduled by solar and astral events. This also appears to be the case for pre-dynastic Egypt (6000-5000 B.P.) and China (4500-3500 B.P.), as well as for North American chiefdoms. After the state was formed in Mexico (2500 B.P.), important rituals were performed by a class of full-time priests, subsidized by society, using religious calendars and occupying temples built at enormous costs in labor and lives. This is also true for the earliest state-level societies of Mesopotamia (after 5500 B.P.) and India (after 4500 B.P.), which, as in Mesoamerica, practiced fearsome human sacrifice (Campbell 1974). Combining this with comparative ethnography suggests that high moralizing gods likely coevolved with costly regularized rituals, creating a mutually reenforcing cultural nexus capable of enhancing internal cooperation and harmony, while providing a justification to exploit out-groups.

Combining these observations with recent work in psychology illuminates a linkage between monumental architecture and religion. The earliest civilizations are known for their impressive monuments, usually in the form of temples, pyramids (tombs), and ziggurats (altars) that may have served at least two important psychological purposes: (1) as costly displays of commitment from the society's leaders, or society in general, they help to instill deeper commitments to religious/group ideologies in learners; and (2) as "religious primes," their visibility may stimulate prosocial behavior. As noted, experiments show that believers give more money to others and cheat less when primed with religious concepts; a giant temple in the market square may provide a salient cue that evokes, if only at the margins, more prosocial behavior. Societies that better exploit these aspects of our psychology could outcompete others.

\section{Cultural Group Selection}

Our species' heavy reliance on social learning spontaneously gives rise to norms and informal institutions (stable equilibria), which vary in their group-level competitive properties. Ecological and social pressures, especially with the spread of agriculture, favor norms and institutions that strengthen and extend the social spheres of cooperation and trust while sustaining internal harmony. Deep commitments to certain kinds of religious beliefs and practices can cement both adherence to prosocial norms and a willingness to sanction norm violators, thereby increasing group solidarity and competitiveness with other groups. Religious beliefs and practices, like groupbeneficial norms, can spread by competition among social groups in several ways, including warfare, economic production, and demographic expansion. Such cultural representations can also spread through more benign interactions, as when members of one group preferentially acquire behaviors, beliefs, and values from more successful groups.
These processes of cultural group selection have both theoretical and empirical grounding. Theoretically, findings from a growing literature of formal models of cultural evolution illuminate three important facts. First, nothing in the modeling of these processes requires "essentializing" culture, nor do these models assume away variation within groups. These models permit within-group variation, and show that cultural group selection can operate even in the face of ample withingroup variation (Boyd and Richerson 2002; Henrich 2004; Boyd et al. 2003). Second, no assumptions about discrete or high fidelity replication are required in models of cultural evolution, and assuming that strong cognitive attractor exists does not obviate the importance of other selective processes (Henrich and Boyd 2002; Henrich et al. 2008). Third, important concerns about older models involving the genetic group selection of altruism do not apply to these cultural evolutionary models. There are several reasons for this but three important ones revolve around: (1) the non-vertical nature of cultural inheritance (Henrich and Boyd 2001), (2) the speed of cultural adaptation (Boyd et al. n.d.), and (3) the presence of multiple stable equilibria (Henrich 2004).

Empirically, both detailed ethnographic studies and historical analyses support the importance of cultural group selection (see Henrich 2009 for additional cases). Ethnographically, to illustrate cultural group selection both via the emulation of more prestigious groups and direct economic competition, consider the well-documented case of three adjoining populations: the Itza' Maya of Guatemala's Petén lowlands, Spanish-speaking Ladino immigrants from diverse regions, and Q'eqchi Maya who arrived in clusters of families and neighbors from the highlands (Atran et al. 2002). Among the Itza' Maya, one important predictor of sustainability is their consensus on supernatural (as opposed to human) forest preferences. This cultural consensus about which species are most valuable and worthy of protection accords well with the anthropogenic character of the forest in the Classic era of Maya civilization. The researchers' hypothesis is that spirit preferences represent a summary of experience accumulated over generations. Itza' Maya believe spirits to be "guardians" of the forest. Spirits help people who do not harm the survival prospects of certain species (as spirits see those prospects). Hurting the forest can result in accidents, illness, and worse (punishment). This research team has witnessed Itza', bitten by deadly pit vipers, refuse to be taken for anticoagulant treatment, until they venture into the forest to ask spirits for guidance or forgiveness. It matters little if supernatural threats are real or not: if people believe in them, threats of punishment become real deterrents (Durkheim 1995).

Evidence indicates that much of this knowledge is being transmitted to Ladinos. Experimental elicitations show that Itza' knowledge predicts relative success in short- and longterm agroforestry. By attending to Itza' models of behavioral 
success in agroforestry, and to Itza' stories that embed that behavior in context, prestigious Ladinos have managed to acquire a subset of Itza' knowledge of the ecological relationships between humans, animals, and plants. Social network analysis suggests how this knowledge and practice has spread through the Ladino community. It seems the initial lack of any communal Ladino religion or corporate structures, combined with the uncertainty created by immigration into a novel environment, made Ladinos open to learning from Itza' (Atran and Medin 2008).

In contrast to Ladinos, migrant Q'eqchi, who have strong and highly ritualized religious institutions, pay little heed to Itza'. The Q'eqchi retain allegiances only to the spirits of their native highlands and have no knowledge of Itza' beliefs. Q'eqchi send delegations back to the highlands to consult deities when they have agricultural troubles in the lowlands. Q'eqchi's mental models of the forest are correspondingly poor, as are their associated agroforestry practices, which are commercially oriented and unsustainable.

These divergent beliefs mean that the Q'eqchi are now spreading more rapidly than the other two groups. In fact, Q'eqchi practices are well adapted to present "open-commons" conditions in Guatemala that encourage massive immigration from the overcrowded highlands into the ecologically fragile lowlands. There is little incentive to avoid destructive practices: if one part of the forest is destroyed, Q'eqchi simply migrate. In this context, Itza' practices are currently maladaptive. By making costly commitments to preserve the forest, Itza' make it easier for the highly ritualized, corporately disciplined Q'eqchi to exploit it. Thus, Itza' may be subsidizing their own cultural extinction in the competition among ethnic groups.

Historically, the impact of the cultural group selection on the interrelationship between religious beliefs and costly rituals/devotions is apparent in a study of 83 utopian communes in the 19th century (Sosis and Bressler 2003). Religious groups with more costly rituals were more likely to survive over time than religious groups with fewer costly rituals. Differential group survival yielded an increase in the mean number of costly rituals per group over time. The above theory and evidence suggest that such rituals and devotions likely generated greater commitment and solidarity within groups (Henrich 2009). Indeed, members and leaders explicitly acknowledged that costly demands increased members' religious commitment (Sosis and Bressler 2003).

The relation of rituals to prosocial behavior toward ingroup members is demonstrated in a variety of ways. Among Israeli kibbutzim (cooperatives), individuals from religious kibbutzim cooperated more in behavioral experiments than those from nonreligious ones, with increased cooperativeness of religious members attributed to greater ritual participation (Sosis and Ruffle 2003). Religious kibbutzim also economically outperform secular ones (Fishman and Goldschmidt
1990; Sosis and Ruffle 2003). Surveys of Palestinians and Israeli settlers in the West Bank and Gaza reveal that a person's frequency of attendance at religious services predicts support for martyrdom missions. This relation is independent of time spent in prayer. Similar findings emerge for representative samples of religious Indians, Russians, Mexicans, British, and Indonesians: Greater ritual attendance predicts both declared willingness to die for one's deities, and belief that other religions are responsible for problems in the world (Ginges et al. 2009). Finally, a study of 60 small-scale societies reveals that males from groups in the most competitive socioecologies (with frequent warfare) endure the costliest rites (genital mutilation, scarification, etc.), which "ritually signal commitment and promote solidarity among males who must organize for warfare" (Sosis et al. 2007).

Cultural group selection shapes religious beliefs and rites to manipulate our psychology to increase solidarity and commitment. Such patterns, observed across history and in the anthropological record, reemerge in today's terrorist groups (Atran 2003). Even avowedly secular national and transnational movements retain many agentive (anthropomorphic) and transcendental (sacred) aspects of traditional religions (Anderson 1991): nations ritually mourn, rejoice, and demand sacrifice, and the "naturalness" of causes that defy prior human history (universal justice, equality, and liberty) is anything but empirically or logically self-evident (Atran 2010). As we argue that sociopolitical complexity coevolved with both commitment-inducing rituals and beliefs in high moralizing gods, our efforts also dovetail with recent work indicating that cultural group selection, driven by differences in sociopolitical complexity, is crucial to understanding the global distribution and diversity of languages (Currie and Mace 2009).

In sum, religion, as an interwoven complex of rituals, beliefs, and norms, plausibly arises from a combination of (1) the mnemonic power of counterintuitive representations, (2) our evolved willingness to put faith on culturally acquired beliefs rooted in the commitment-inducing power of devotions and rituals, and (3) the selective effect on particular cultural complexes created by competition among societies and institutions. None of these evolved for religion per se. The mnemonic power of minimally counterintuitive representations appears to be a by-product of our evolved expectations about how the world works and our fitness-enhancing requirement to pay attention to anomalies. The faith we sometimes place in culture over our own experience and intuitions is a cognitive adaptation, resulting from our long dependence on vast bodies of complex cultural knowledge. Reliance on costly displays evolved to provide partial immunity against manipulation. The power of rhythm and synchrony in ritual to build solidarity (Wiltermuth and Heath 2009) likely arises from our imitative and ToM abilities. Cultural evolution, driven by competition among groups, exploits each of these cognitive processes to fashion sets of 
counterintuitive beliefs, rituals, and norms that spread by intergroup transmission, conquest, or reproductive differentials. As a result, for large-scale societies, these complexes tend to include potent supernatural agents that monitor and incentivize actions that expand the sphere of cooperation, galvanize solidarity in response to external threats, deepen faith, and sustain internal harmony.

Significant advances in the study of religious cognition, the transmission of culture, and the evolution of cooperation are all relatively recent. Bringing these new insights, in combination with older ideas, to bear on phenomena as complex as moralizing religions and large-scale societies will be an ongoing challenge. The argument and evidence presented here provides a plausible scenario showing how synthetic progress is possible. More rigorous study is needed on the evolved psychology and cultural processes associated with the role of counterintuitive agents and costly rituals in scaling up the scope of trust and exchange of sacred values and taboos in sustaining large-scale cooperation against external threats, and also of maintaining social and political causes that defy selfinterest. Empirical research that combines in-depth ethnography with both cognitive and behavior experiments among diverse societies, including those lacking a world religion, is crucial to understanding how religion influences our cognition, decision-making, and judgments. The formal modeling of cultural evolutionary processes should be combined with historical and archeological efforts to apply these emerging insights to broad patterns of history. These joint efforts should further illuminate the origins and development of religions, and the cooperation and conflicts they engender. There may be no more urgent study needed in the world today.

\section{Acknowledgments}

This material is based upon work supported by the National Science Foundation under grant number SBE-0527396. We thank Ara Norenzayan and Robert Axelrod for commentary.

\section{References}

Alcorta CS, Sosis R (2005) Ritual, emotion, and sacred symbols: The evolution of religion as an adaptive complex. Human Nature 1: 323-359.

Allen-Arave W, Gurven M, Hill K (2008) Reciprocal altruism, rather than kin selection, maintains nepotistic food transfers on an Ache reservation. Evolution and Human Behavior 29: 305-318.

Anderson B (1991) The Imagined Communities: Reflections on the Origin and Spread of Nationalism. London: Verso.

Argyle M, Beit-Hallahmi B (2000) The Social Psychology of Religion. New York: Routledge.

Atran S (1998) Folkbiology and the anthropology of science: Cognitive universals and cultural particulars. Behavioral and Brain Sciences 21: 547 609.

Atran S (2002) In Gods We Trust. New York: Oxford University Press.

Atran S (2003) Genesis of suicide terrorism. Science 299: 1534-1539.

Atran S (2010) Talking to the Enemy: Faith, Brotherhood, and the (Un)Making of Terrorists. New York: Ecco/Harper Collins.
Atran S, Axelrod R, Davis R (2007) Sacred barriers to conflict resolution. Science 317: 1039-1040.

Atran S, Medin DL (2008) The native mind and the cultural construction of nature. Cambridge, MA: MIT Press.

Atran S, Medin D, Ross N, Lynch E, Vapnarsky V, Ek' EU, Coley J, Timura C, Baran M (2002) Folkecology, cultural epidemiology, and the spirit of the commons: A garden experiment in the Maya lowlands, 1991-2001. Current Anthropology 43: 421-450.

Atran S, Norenzayan A (2004) Religion's evolutionary landscape: Counterintuition, commitment, compassion, communion. Behavioral and Brain Sciences 27: 713-770.

Atran S, Sperber D (1991) Learning without teaching. In: Culture, Schooling and Psychological Development (Tolchinsky-Landsmann L, ed), 39-55. Norwood, NJ: Ablex.

Bargh JA, Chartrand TL (1999) The unbearable automaticity of being. American Psychologist 54: 462-479.

Baron-Cohen S (1995) Mindblindness. Cambridge, MA: MIT Press.

Barrett JL (1998) Cognitive constraints on Hindu concepts of the divine. Journal for the Scientific Study of Religion 37: 608-619.

Barrett JL (2000) Exploring the natural foundations of religion. Trends in Cognitive Science 4: 29-34.

Barrett JL (2004) Why Would Anyone Believe in God? Walnut Creek, CA: AltaMira Press.

Barrett JL, Keil FC (1996) Conceptualizing a nonnatural entity: Anthropomorphism in God concepts. Cognitive Psychology 31: 219-247.

Barrett JL, Nyhof MA (2001) Spreading nonnatural concepts. Journal of Cognition and Culture 1: 69-100.

Beck W (1992) Aboriginal preparation of Cycads seeds in Australia. Economic Botany 46: 133-147.

Bloom P, Veres C (1999) The perceived intentionality of groups. Cognition 71: B1-B9.

Boyd R, Gintis H, Bowles S, Richerson PJ (2003) The evolution of altruistic punishment. Proceedings of the National Academy of Sciences of the USA 100: 3531-3535.

Boyd R, Richerson P (1988) The evolution of reciprocity in sizable groups. Journal of Theoretical Biology 132: 337-356.

Boyd R, Richerson P (2002) Group beneficial norms can spread rapidly in a structured population. Journal of Theoretical Biology 215: 287296.

Boyd R, Richerson J, Henrich J (n.d.) Rapid cultural adaptation can facilitate the evolution of large-scale cooperation. Manuscript. University of British Columbia.

Boyer P (2001) Religion Explained. New York: Basic Books.

Boyer P, Ramble C (2001) Cognitive templates for religious concepts: Crosscultural evidence for recall of counter-intuitive representations. Cognitive Science 25: 535-564.

Campbell J (1974) The Mythic Image. Princeton, NJ: Princeton University Press.

Csibra G, Gergely G, Bíró S, Koós O, Brockbank M (1999) Goal attribution without agency cues. Cognition 72: 237-267.

Currie TE, Mace R (2009) Political complexity predicts the spread of ethnolinguistic groups. Proceedings of the National Academy of Sciences USA 106: 7339-7344.

Dehghani M, Iliev R, Sachdeva S, Atran S, Ginges J, Medin D (2009) Emerging sacred values: The Iranian nuclear program. Judgment and Decision Making 4: 990-993.

Diesendruck G, Haber L (2009) God's categories: The effect of religiosity on children's teleological and essentialist beliefs about categories. Cognition 110: $100-114$

Durkheim E (1995) Elementary Forms of Religious Life. New York: Free Press. 
Ensminger J (1997) Transaction costs and Islam: Explaining conversion in Africa. Journal of Institutional and Theoretical Economics 153: 4-28.

Fehr E, Fischbacher U (2003) The nature of human altruism. Nature 425: 785-791.

Festinger L, Riecken H, Schachter S (1956) When Prophecy Fails. Minneapolis, MN: University of Minnesota Press.

Firth R (1963) Offering and sacrifice. Journal of the Royal Anthropological Institute 93: 12-24.

Fishman A, Goldschmidt Y (1990) The orthodox kibbutzim and economic success. Journal for the Scientific Study of Religion 29: 505-511.

Freston P (2001) Evangelicals and Politics in Asia, Africa and Latin America. New York: Cambridge University Press.

Gazzaniga MS, Ivry RB, Mangun GR (2009) Cognitive Neuroscience, 3rd ed. New York: Norton.

Gervais W, Henrich J (forthcoming) The Zeus problem: Why representational content biases cannot explain faith in gods. Journal of Cognition and Culture.

Ginges J, Atran S, Medin DL, Shikaki K (2007) Sacred bounds on rational resolution of violent political conflict. Proceedings of the National Academy of Sciences of the USA 104: 7357-7360.

Ginges J, Hansen I, Norenzayan A (2009) Religious and popular support for suicide attacks. Psychological Science 20: 224-230.

Gintis H, Smith EA, Bowles S (2001) Costly signaling and cooperation. Journal of Theoretical Biology 213: 103-119.

Greeley A (1975) The Sociology of the Paranormal. Beverly Hills, CA: Sage. Guthrie S (1993) Faces in the Clouds. New York: Oxford University Press.

Harper L, Sanders KM (1975) The effect of adults' eating on young children's acceptance of unfamiliar foods. Journal of Experimental Child Psychology 20: 206-214.

Harris P, Pasquini ES, Duke S, Asscher JJ, Pons F (2006) Germs and angels: The role of testimony in young children's ontology. Developmental Science 9: 76-96.

Heider F, Simmel S (1944) An experimental study of apparent behavior. American Journal of Psychology 57: 243-259.

Henrich J (2004) Cultural group selection, coevolutionary processes and largescale cooperation. Journal of Economic Behavior and Organization 53: $3-35$.

Henrich J (2008) A cultural species. In: Explaining Culture Scientifically (Brown M, ed), 184-210. Seattle, WA: University of Washington Press.

Henrich J (2009) The evolution of costly displays, cooperation, and religion: Credibility enhancing displays and their implications for cultural evolution. Evolution and Human Behavior 30: 244-260.

Henrich J, Boyd R (2001) Why people punish defectors: Weak conformist transmission can stabilize costly enforcement of norms in cooperative dilemmas. Journal of Theoretical Biology 208: 79-89.

Henrich J, Boyd R (2002) On modeling cognition and culture: Why replicators are not necessary for cultural evolution. Journal of Cognition and Culture 2: 87-112.

Henrich J, Boyd R, Bowles S, Camerer C, Fehr E, Gintis H, McElreath R, Alvard M, Barr A, Ensminger J, Hill K, Gil-White F, Gurven M, Marlowe F, Patton JQ, Smith N, Tracer D (2005) "Economic man" in crosscultural perspective: Behavioral experiments in 15 small-scale societies. Behavioral and Brain Sciences 28: 795-815.

Henrich J, Boyd R, Richerson P (2008) Five misunderstandings about cultural evolution. Human Nature 10: 253-289.

Henrich J, Ensminger J, McElreath R, Barr A, Barrett C, Bolyanatz A, Cardenas JC, Gurven M, Gwako E, Henrich N, Lesorogol C, Marlowe F, Tracer F, Ziker J (2010) Markets, religion, community size, and the evolution of fairness and punishment. Science 327: 1480-1484.

Henrich J, Gil-White F (2001) The evolution of prestige. Evolution and Human Behavior 22: 165-196.
Henrich J, McElreath R (2003) The evolution of cultural evolution. Evolutionary Anthropology 12: 123-135.

Henrich NS, Henrich J (2007) Why Humans Cooperate: A Cultural and Evolutionary Explanation. Oxford: Oxford University Press.

Horner V, Whiten A (2005) Causal knowledge and imitation/emulation switching in chimpanzees and children. Animal Cognition 8: 164-181.

Hruschka D, Henrich J (2006) Friendship, cliquishness, and the emergence of cooperation. Journal of Theoretical Biology 239: 1-15.

Irons W (1996) In our own self-image. Skeptic 4(2): 50-52.

Johnson D (2005) God's punishment and public goods. Human Nature 16: 410-446.

Johnson G (1987) In the name of the fatherland: An analysis of kin term usage in patriotic speech and literature. International Political Science Review 8: $165-174$.

Kapogiannis D, Barbey AK, Su M, Zamboni G, Krueger F, Grafman J (2009) Cognitive and neural foundations of religious belief. Proceedings of the National Academy of Sciences of the USA 106: 4876-4881.

Keil F (1979) Semantic and Conceptual Development. Cambridge, MA: Harvard University Press.

Keleman D (2004) Are children "intuitive theists"? Reasoning about purpose and design in nature. Psychological Science 15: 295-301.

Khaldûn I (2005) The Muqaddimah: An Introduction to History. Princeton, NJ: Princeton University Press.

Klein RG (1989) The Human Career: Human Biological and Cultural Origins. Chicago, IL: University of Chicago Press.

Kluckholn C, Leighton D (1946) The Navajo. Cambridge, MA: Harvard University Press.

Lee R (1979) The !Kung San: Men, Women and Work in a Foraging Society. New York: Cambridge University Press.

Levy R (1957) The Social Structure of Islam. Cambridge, UK: Cambridge University Press.

Liebenberg L (1990) The Art of Tracking. Cape Town, South Africa: David Philip Publishers.

Lyons DE, Young AG, Keil FC (2007) The hidden structure of overimitation. Proceedings of the National Academy of Sciences of the USA 104: 1975119756.

Malley B (2004) How the Bible Works: An Anthropological Study of Evangelical Biblicism. Walnut Creek, CA: AltaMira Press.

Marcus J, Flannery KV (2004) The coevolution of ritual and society: New C-14 dates from ancient Mexico. Proceedings of the National Academy of Sciences of the USA 101: 18257-18261.

Marks L (2004) Sacred practices in highly religious families. Family Process 43: 217-231.

Mathew S, Boyd R (2009) When does optional participation allow the evolution of cooperation? Proceedings of the Royal Society B 276: 11671174.

Mazar N, Ariely D (2006) Dishonesty in everyday life and its policy implications. Journal of Public Policy and Marketing 25: 117-126.

McElreath R, Boyd R, Richerson PJ (2003) Shared norms and the evolution of ethnic markers. Current Anthropology 44: 122-129.

McNeil WH (1982) Pursuit of Power. Chicago, IL: University of Chicago Press.

McNeil WH (1991) The Rise of the West. Chicago, IL: University of Chicago Press.

Norenzayan A, Atran S, Faulkner J, Schaller M (2006) Memory and mystery: The cultural selection of minimally counterintuitive narratives. Cognitive Science 30: 531-553.

Norenzayan A, Hansen IG (2006) Belief in supernatural agents in the face of death. Personality and Social Psychology Bulletin 32: 174-187.

Norenzayan A, Shariff AF (2008) The origin and evolution of religious prosociality. Science 322: 58-62. 
Norris P, Inglehart R (2004) Sacred and Secular. New York: Cambridge University Press.

Nowak MA, Sigmund K (2005) Indirect reciprocity. Nature 437: 12911298.

Panchanathan K, Boyd R (2003) A tale of two defectors: The importance of standing for the evolution of indirect reciprocity. Journal of Theoretical Biology 224: 115-126.

Panchanathan K, Boyd R (2004) Indirect reciprocity can stabilize cooperation without the second-order free rider problem. Nature 432: 499-502.

Phillips A (1970) Ancient Israel's Criminal Law: A New Approach to the Decalogue. New York: Schocken.

Pyysiäinen I (2003) Buddhism, religion, and the concept of "God.” NumenInternational Review for the History of Religions 50: 147-171.

Rakoczy H, Wameken F, Tomasello M (2008) The sources of normativity: Young children's awareness of the normative structure of games. Developmental Psychology 44: 875-881.

Rappaport RA (1999) Ritual and Religion in the Making of Humanity. Cambridge, UK: Cambridge University Press.

Richerson P, Boyd R (2005) Not by Genes Alone. Chicago, IL: University of Chicago Press.

Roes FL (1995) The size of societies, stratification, and belief in high gods supportive of human morality. Politics and the Life Sciences 14: 73-77.

Roes FL, Raymond M (2003) Belief in moralizing gods. Evolution and Human Behavior 24: 126-135.

Ruffle BJ, Sosis R (2006) Cooperation and the in-group out-group bias: A field test on Israeli kibbutz members and city residents. Journal of Economic Behavior and Organization 60: 147-163.

Shariff AF, Norenzayan A (2007) God is watching you. Psychological Science 18: 803-809.

Smith C (1996) Disruptive Religion. New York: Routledge.
Sosis R, Alcorta C (2003) Signaling, solidarity, and the sacred: The evolution of religious behavior. Evolutionary Anthropology 12: 264-274.

Sosis R, Bressler ER (2003) Cooperation and commune longevity: A test of the costly signaling theory of religion. Cross-Cultural Research 37: 211-239.

Sosis R, Kress H, Boster J (2007) Scars for war. Evolution and Human Behavior 28: 234-247.

Sosis R, Ruffle BJ (2003) Religious ritual and cooperation: Testing for a relationship on Israeli religious and secular kibbutzim. Current Anthropology 44: 713-722.

Sperber D (1996) Explaining Culture: A Naturalistic Approach. Oxford: Blackwell.

Sperber D, Premack D, Premack A, eds (1995) Causal Cognition. New York: Oxford University Press.

Stark R (1997) The Rise of Christianity. New York: Harper Collins.

Sweeney M (2001) King Josiah of Judah. New York: Oxford University Press.

Tetlock P (2003) Thinking the unthinkable: Sacred values and taboo cognitions. Trends in Cognitive Science 7: 320-324.

Trainor L, Trehub S (1992) The development of referential meaning in music. Music Perception 9: 455-470.

Whitehouse H (2004) Modes of Religiosity: A Cognitive Theory of Religious Transmission. Walnut Creek, CA: AltaMira Press.

Whitson JA, Galinsky AD (2008) Lacking control increases illusory pattern perception. Science 322: 115-117.

Whythe WF (1993) Street Corner Society: The Social Structure of an Italian Slum. Chicago, IL: University of Chicago Press.

Wilson DS (2002) Darwin's Cathedral: Evolution, Religion, and the Nature of Society. Chicago, IL: University of Chicago Press.

Wiltermuth SS, Heath C (2009) Synchrony and cooperation. Psychological Science 20: 1-5. 